\title{
Science, religion and ethics: The Boyle Lecture 2019
}

\author{
Michael J Reiss
}

\begin{abstract}
How do we and should we decide what is morally right and what is morally wrong? For much of human history, the teachings of religion were presumed to be either the or a principal answer. Over time, two developments challenged this. The first was the establishment of the discipline of moral philosophy. Foundational texts, such as Kant's Groundwork of the Metaphysics of Morals, and the growth of coherent, non-religious approaches to ethics, notably utilitarianism, served to marginalise the role of religion. And then, secondly, the twentieth century saw the rapid growth of evolutionary biology with an enthusiastic presumption that biology was the source of ethics. Here, I begin by discussing these developments and then examine the extent to which religion is still needed for a coherent account of ethics.
\end{abstract}

Keywords: $\quad$ morality; ethics; evolutionary ethics; virtue theory

The Boyle Lectures were established in 1692, upon the death of the celebrated seventeenth-century natural philosopher, theologian, and chemist, Robert Boyle (16271691). The original purpose of the lectures was to defend Christian theology against unbelief; however, in practice the lectures have become known for their explorations of the relationship between Christian theology and the natural sciences. This present article gives a slightly expanded version of the 2019 Boyle Lecture delivered in St Mary-le-Bow Church, London, on 18th February 2019.

Michael J Reiss is Professor of Science Education at UCL Institute of Education, University College London, UK and President of the International Society for Science and Religion; email: $\underline{\text { m.reiss@ucl.ac.uk. }}$

\section{ETHICS}

Ethics is the branch of philosophy concerned with how we should decide what is morally wrong and what is morally right. We all have to make moral decisions daily on matters great or (more often) small about what is the right thing to do: Should I continue to talk to someone for their benefit or make my excuse and leave to do something else? Should I give money to animal charities or to medical charities? Should I give more weight to my interests than to those of others when choosing for whom to vote in an election?

We may give much thought, little thought or practically no thought at all to such questions. Ethics, though, insofar as it is worth trying to make a clear distinction between it and morality, is a specific discipline that tries to probe the reasoning behind our moral life, 
particularly by critically examining and analysing the thinking which is or could be used to justify our moral choices and actions in particular situations (Reiss 2002).

\section{The way ethics is done}

Ethics is both a practice and, just as other intellectual disciplines, such as science, mathematics and history, are, a branch of knowledge. Ethical thinking is not wholly distinct from thinking in other disciplines but it cannot simply be reduced to them. Furthermore, ethical conclusions cannot be unambiguously proved in the way that mathematical theorems can. However, this does not mean that all ethical conclusions are equally valid. Some ethical conclusions are more likely to be valid than others.

One can be most confident about the validity and worth of an ethical conclusion if three criteria are met (Reiss 1999). First, if the arguments that lead to the particular conclusion are convincingly supported by reason. Secondly, if the arguments are conducted within a well-established ethical framework. Thirdly, if a reasonable degree of consensus exists about the validity of the conclusions, arising from a process of genuine debate.

It might be supposed that reason alone is sufficient for one to be confident about an ethical conclusion. However, there are problems in relying on reason when thinking ethically. In particular, there still does not exist a single universally accepted framework within which ethical questions can be decided by reason (O'Neill 1996; Parfit 2011). Indeed, it is unlikely that such a framework will exist in the foreseeable future, if ever. This is not to say that reason is unnecessary but to acknowledge that reason alone is insufficient. For instance, reason cannot decide between an ethical system which looks only at the consequences of actions and one which considers whether certain actions are right or wrong in themselves, whatever their consequences. Much of ethics still boils done to views about right and wrong informed more about what seems 'reasonable' than what follows from formal reasoning. When I, with a background in mathematics and the natural sciences, first started reading books on ethics, I was surprised at how often appeals to intuition were used. Indeed, when reading about 'trolley problems' (Foot 1967; Unger 1996), intuition not infrequently appears as a trump card. Mathematicians and those who work in the natural sciences are rarely convinced by appeals to intuition (consider, quantum mechanics and relativity).

Indeed, anyone with a background in evolutionary biology will be rather suspicious about intuition as a means of arriving at truth. Intuition is one of the ways in which humans make decisions. Unsurprisingly, having been honed by millions of years of natural selection, it is rather effective. But we need always to remember that natural selection is, roughly speaking (I shall have more to say about this below), all about leaving as many copies of oneself in future generations as one can. The emphasis is on survival and reproduction not truth (Abrahams and Reiss 2012).

For example, we hear silences between the words in a conversation whereas the information gathered by a microphone 'listening' to the same conversation shows that these silences are, objectively, as noisy as are many of the words. The gaps we hear 
between words are very largely gaps inserted by our minds to render the stream of auditory information more intelligible.

Similarly, our visual system is far more sensitive, to give just one example, to movement than to non-movement. Now the evolutionary advantages of this are clear: a mother needs to be sensitive to changes in the behaviour of her child(ren) and changes are often indicated by movement; hunters need to be alert to the movements of possible prey; and so on. Indeed, we share this hypersensitivity to movement with many other species - the classic work was done on frogs back in the early 1950s (Barlow 1953). This is an illustration of the fact that it is not only humans that sense only part of the world and emphasise other parts of it, so that we really do construct the world around us; this is a characteristic we share, to varying degrees, with all of life including the first unicellular organism that evolved the ability to detect the presence of certain chemicals in its surroundings and so was able to spend more time in places where there was more food.

The simplest way of summarising all this is to say that the external world is a complex world and even the human mind, in all its richness and complexity, simply has neither the capacity nor the need to obtain a full, detailed map of it. Rather, we have evolved to get through life and leave offspring that have an above average chance of doing the same. Often, truth and evolutionary success go hand in hand - there is little to be gained in under- or overestimating the nutritional value in different foods, for example. However, even here the fact that today's environment is so different from that in which we spent much of our evolutionary history causes problems. As is well known, most people have a greater liking for saturated fats and for sugars than is good for them. This can cause problems for those of us who now live with a superabundance of foods rich in such ingredients. In the past, of course, there was little to be gained - and much to be risked - in not stuffing ourselves when an occasional glut of such foods presented themselves.

The insufficiency of reason is a strong argument for conducting debates about ethics within well-established ethical frameworks, when this is possible. Traditionally, the ethical frameworks most widely accepted in most cultures arose within systems of religious belief. Consider, for example, the questions 'Is it wrong to lie? If so, why?'. There was a time when the majority of people in many countries would have accepted the answer ' $Y$ es, because scripture forbids it'. Nowadays, though, not everyone accepts scripture(s) as a source of authority. Another problem, is that while the various scriptures of the world's religions have a great deal to say about such issues as theft, killing people and sexual behaviour, they say rather less that can directly be applied to the debates that surround many of today's ethical issues, for example those involving modern biotechnology.

A further issue is that we are more aware nowadays that we live in multicultural or pluralist societies. Within most countries there is no longer a single shared set of moral values. Nevertheless, there is still great value in taking seriously the various traditions - religious and otherwise - that have given rise to ethical conclusions. People do not live their lives in ethical isolation: they grow up within particular moral traditions. Even if we end up departing somewhat from the values we received from our families and those around us as we grew up, none of us derives our moral beliefs from first principles, ex nihilo, as it were. 
Given, then, the difficulties in relying solely on either reason or any one particular ethical tradition, we are forced to consider the approach of consensus (Moreno 1995). It is true that consensus does not solve everything. After all, what does one do when consensus cannot be arrived at? Nor can one be certain that consensus always arrives at the right answer - a consensus once existed that women should not have the vote and that beating was good for children.

Nonetheless, there are good reasons both in principle and in practice in searching for consensus. Such a consensus should be based on reason and genuine debate and take into account long-established practices of ethical reasoning. At the same time, it should be open to criticism, refutation and the possibility of change. Finally, consensus should not be equated with majority voting. Consideration needs to be given to the interests of minorities, particularly if they are especially affected by the outcomes, and to those - such as young children, the mentally infirm and non-humans - unable to participate directly in the decision-making process. It also needs to be born in mind that while a consensus may eventually emerge, there is a time when what is more important is simply to engage in valid debate in which the participants respect one another, so far as is possible, and seek for truth through dialogue (cf. Habermas 1983; Martin 1999).

I wrote above that there still does not exist a single universally accepted framework within which ethical questions can be decided by reason. The simplest approach to deciding whether an action would be right or wrong is to look at what its consequences would be. No one supposes that we can ignore the consequences of an action before deciding whether or not it is right. The deeper question is whether all that we need to do is to look at consequences. Or is it that there are certain actions that are morally required - such as telling the truth - whatever their consequences? Are there other actions - such as betraying confidences - that are wrong whatever their consequences?

Consequentialists hold that consequences alone are sufficient to let one decide the rightness or otherwise of a course of action. As is well known, the most widespread form of consequentialism is known as utilitarianism. Utilitarianism begins with the assumption that most actions lead to pleasure (typically understood, at least for humans, as happiness) and/or displeasure. In a situation in which there are alternative courses of action, the right action is the one that leads to the greatest net increase in pleasure (i.e. excess of pleasure over displeasure, where displeasure means the opposite of pleasure, i.e. harm).

Utilitarianism as a significant movement arose in Britain at the end of the eighteenth century with the work of Jeremy Bentham and J. S. Mill. However, its roots are much earlier. In the fifth century BCE Mo Tzu in China argued that all actions should be evaluated by their fruitfulness and that love should be all-embracing. Nowadays, it exists in various forms (preference utilitarianism, act utilitarianism, rule utilitarianism, etc) but what all utilitarians hold in common is the rejection of the view that certain things are right or wrong in themselves, irrespective of their consequences. Consider, for example, the question as to whether or not we should tell the truth. A utilitarian would not provide an unqualified 'yes' as a universal answer. 
There are at least two great strengths of utilitarianism. First, it provides a single ethical framework within which, in principle, any moral question may be answered. It doesn't matter whether we are talking about the legalisation of cannabis, the age of sexual consent or the use of animals for school dissection, a utilitarian perspective exists. Secondly, utilitarianism takes pleasure and happiness seriously. The general public may sometimes suspect that ethics is all about telling people what not to do. Utilitarians proclaim the positive message that people should simply do what maximizes the total amount of pleasure in the world.

However, there are difficulties with utilitarianism as the sole arbiter in ethical decision making. For one thing, there is the question as to how pleasure can be measured. For a start, is it to be equated with well-being, the subjective experience of happiness or the fulfilment of choice? And, anyway, what are its units? How can we compare different types of pleasure, for example sexual and aesthetic? Then, is it always the case that two units of pleasure should outweigh one unit of displeasure? Suppose two people each need a single kidney. Should one person (with two kidneys) be killed so that two may live (each with one kidney)?

Utilitarians claim to provide answers to all such objections (e.g. Singer 2011). For example, rule-based utilitarianism accepts that the best course of action is often served by following certain rules - 'Tell the truth', for example. Then, a deeper analysis of the kidney example suggests that if society really did allow one person to be killed so that two others could live, many of us might spend so much of our time going around fearful that the sum total of human happiness would be less than if we outlawed such practices.

The major alternative to utilitarianism is a form of ethical thinking in which certain actions are considered right and others wrong in themselves, i.e. intrinsically, regardless of the consequences. Consider, for example, the question as to whether a society should introduce capital punishment. A utilitarian would decide whether or not capital punishment was morally right by attempting to quantify the effects it would have on the society. Large amounts of empirical data would probably need to be collected, comparing societies with capital punishment and those without it with regard to such things as crime rates, the level of fear experienced by people worried about crime and the use to which any money saved by the introduction of capital punishment might be put. On the other hand, someone could argue that regardless of the consequences of introducing capital punishment, it is simply wrong to take a person's life, whatever the circumstances. Equally, someone could argue that certain crimes, for example first degree murder, should result in the death penalty that this simply is the right way to punish such a crime.

There are a number of possible intrinsic ethical principles. Perhaps the most widely discussed are those of autonomy and justice. People act autonomously if they are able to make their own informed decisions and then put them into practice. Autonomy is concerned with an individual's rights; justice is construed more broadly, being principally about fair treatment and the fair distribution of resources or opportunities. Of course, considerable disagreement exists about what precisely counts as fair treatment and a fair distribution of resources. For example, some people accept that an unequal distribution of certain resources (e.g. educational opportunities) may be fair provided certain other criteria 
are satisfied (e.g. the educational opportunities are purchased with money legally earned or inherited).

More fundamentally, Kant, in his Groundwork of the Metaphysics of Morals (Kant 1785/2012), argued, in the first formulation of his categorical imperative, that we should act only according to that maxim whereby we can, at the same time, will that it should become a universal law. In other words, we should never do those things which favour us merely because we are us. This forbids such actions as theft and telling lies. It is, of course, close to the Golden Rule that we should treat others as we would like to be treated if we were them; we are called to love our neighbours as ourselves.

A rather different approach to the whole issue of ethics is provided by virtue ethics. Instead of starting from particular actions and trying to decide whether they fail to maximise the amount of happiness in the world, are divinely forbidden or infringe someone's rights, virtue ethics focuses on the moral characteristics of good people. For example, what characteristics might we expect a good teacher to manifest? We might want them to know their subject, to treat all students fairly, to be able to maintain order in the classroom, to maximise students' chances of doing well in any examinations, to be able to communicate clearly, to have a sense of humour and so on. Some of these are skills - for example the ability to maintain classroom order - but some are personality traits that we call virtues, notably, treating all students fairly.

Virtue ethics has an ancient pedigree - receiving considerable impetus from Aristotle - and has undergone something of a revival since the 1970s (Kristjánsson 2015). Part of the reason for this may be connected with a somewhat instrumental tendency in much of the training of such professionals as doctors, nurses, lawyers, accountants and so on, in which the idea of moral goodness features little. And yet many people who have to deal with such professionals (as patients and clients) want them to manifest virtues as well as be knowledgeable and technically skilled. Furthermore, when we look at various abuses in the professions, it is clear that many of these would have been much less likely to have occurred had all those in these professions been disposed to behave virtuously. I will return to virtue ethics below but first, let me introduce a very different approach to understanding what we consider to be morally right and to determining what is morally right.

\section{EVOLUTIONARY ETHICS}

My background is in evolutionary biology. One of the great triumphs of the last 150 years has been for us to realise how the theory of natural selection, as first brought into prominence by Charles Darwin and Alfred Russel Wallace, can explain so much of the natural world. We are used to thinking how natural selection can be invoked to understand the morphology of organisms - the wings of a bird, a polar bear's insulation and a cheetah's flexible spine. But Darwin realised that natural selection does not apply only to structures, it applies also to behaviours. Birds fly with their wings, polar bears rely on their insulation while out on the ice and the flexible spine of a cheetah enables it to outrun its prey. 
Darwin realised that the same arguments that apply to the behaviour of non-human animals also apply to humans. His The Descent of Man, and Selection in Relation to Sex (Darwin 1871) and The Expression of the Emotions in Man and Animals (Darwin 1872) explore the ramifications of natural selection for human behaviours and emotions. Even though Darwin knew nothing of the mechanism of inheritance, he realised that natural selection might still be responsible for the evolution of worker sterility in the social insects. At first sight, such sterility deals a crushing blow for the theory of natural selection. Such individuals produce no offspring - so how can this be functional?

Darwin argued that sterility in such circumstances might evolve by a process he termed 'family selection', nowadays generally known as 'kin selection'. He pointed out that "breeders of cattle wish the flesh and fat to be well marbled together; the animal has been slaughtered, but the breeder goes with confidence to the same family" (Darwin 1859, p. 358). In other words, both artificial and natural selection do not have to rely on individuals having their own offspring; individuals can reproduce vicariously, as it were, via their close relatives. This can allow altruism - even extreme altruism in which individuals do not reproduce - to evolve and perpetuate.

Darwin's thoughts about altruism largely lay dormant for a century until a PhD student called William D. Hamilton produced a more general, mathematical theory that encapsulated Darwin's insights about the origins of altruism. Advances came thick and fast and the 1960s and '70s saw an explosion in field work and in theoretical modelling in the disciplines that came to be known as behavioural ecology and sociobiology. As is often the case when new disciplines arise, we can see with hindsight that those working in the field sometimes overstretched themselves and the work of Richard Dawkins, E. O. Wilson and others, particularly when extrapolations were made to human behaviour, had to be tempered by the work of Stephen Jay Gould, Richard Lewontin, Steven Rose and others. Furthermore, there are still areas of disagreement - notoriously with regards to the level at which selection operates, namely whether selection at the level of genes and individuals is all that needs be considered or whether selection operating between groups of individuals results in phenomena that cannot be explained solely by selection at lower levels (Sober and Wilson 1998; Nowak and Coakley 2013). Nevertheless, advances were made and a new subdiscipline arose: 'evolutionary ethics' (Maienschein and Ruse 1999; Hauser 2006; de Waal et al. 2014; Ruse and Richards 2017), though the fundamental questions have been around for much longer (Woodford 2018).

Evolutionary ethics has proved to be extremely controversial. Let me begin by clarifying that what science does is to attempt to explain why the world is as it is - what is there and how it operates; separately, we can then consider whether the world is as we wish it to be and, if it isn't, what we might do about it. Considering evolutionary ethics as a science results in lots of interesting findings - ones that 'make sense'. I have already briefly referred to Darwin's insights into the explanation for worker sterility in the social insects. Subsequent gains in knowledge sometimes complicate matters (for instance, the predictions depend on the extent to which queen bees, ants and wasps mate with just one male or with more than one) and there have been new theoretical developments (for example, in games theory where an individual's best strategy depends on what other individuals do). Nevertheless, in most species most behaviour falls into one of three categories: 
- It favours the individual concerned (individual selfishness). Consider individuals feeding by themselves - they simply forage so as to maximise their intake of energy and limiting nutrients while attempting to minimise their exposure to predation, inclement weather or other hazards.

- It favours close relatives (kin selection). Strictly speaking, most biologists see any instance of parental investment in offspring as falling into this category but more dramatic examples are afforded by cases, such as in the social insects and naked mole rats, where individuals help their non-offspring to reproduce at their own expense.

- It favours unrelated individuals who subsequently reciprocate (reciprocal altruism). To give a classic example, vampire bats (Desmodus rotundus) are colonial mammals. During the day, they roost together, often in hollow trees. At night they feed on the blood of domestic animals, such as cattle, horse, goats and pigs. If an individual fails to find a meal on two successive nights, it is in deep trouble: Wilkinson (1984) found that after about 50-60 hours without blood, a vampire bat starves to death. At his study sites, Wilkinson found that fully $18 \%$ of individuals failed to obtain a meal on any one night. What Wilkinson also found was that a bat that had failed to obtain a meal was usually provided with regurgitated blood by a roostmate that had successfully fed the previous night. Often, such altruism was provided by a mother for her offspring. However, on a number of occasions, the bat receiving regurgitated food was either unrelated or only distantly related to the bat providing the food. Furthermore, it looked as though individuals remembered from which individuals they had received blood and subsequently reciprocated to these individuals.

There are examples of behaviour that fall outside these three categories. For example, consider 'meiotic drive'. From the middle of the twentieth century, examples have been known from a range of species where one or more of the genes in a genome manipulate the process of meiotic cell division so that the genes in question are over-represented in the next generation. At first considered an evolutionary oddity, such behaviour is best understood by Richard Dawkins' selfish gene view of life (Dawkins 1976). The essence of this view is that to understand organisms we should pay attention to the interests of the genetic material that contributes to their structures and behaviours. Often, we can pretty much understand what is going on by focusing only on the phenotypes of organisms - that is, their appearances. Phenomena like meiotic drive remind us that we need to understand matters from the perspective of organisms' genetic material too.

Back to animal behaviour: individual selfishness, kin selection and reciprocal altruism do indeed 'make sense'. And to an evolutionary biologist so too does the everyday finding that the great majority of people are more concerned about the welfare of close relatives, reproductive partners or those with whom they regularly interact (enabling reciprocal altruism) than they are about the welfare of others.

We see the non-human equivalent of this when we watch nature programmes. Individual non-human animals often treat other individuals in the same species very differently depending on whether they are group members or not. I therefore belong to the camp that sees such unwanted human behaviours as xenophobia and, more generally, selfishness as 
having their origins in our biology - but I emphasise 'origins'. Non-humans are not xenophobic in the way that humans can be and undesirable human traits such as racism and sexism, while they are not entirely unconnected to related behaviours in non-humans, cannot simply be reduced to them. To give one specific example, there was a furore when evolutionary biologist Randy Thornhill and anthropologist Craig Palmer co-authored $A$ Natural History of Rape (Thornhill and Palmer 2000), arguing, in part from analogous behaviours in a number of non-human species, that rape arises for evolutionary reasons and contradicting the argument that rape is not sexually motivated. Their book received mixed reviews - and some of the most negative ones came from male evolutionary biologists. For instance, the primatologist Frans de Waal started by stating that "Rape is sexual violence. There is no doubt in my mind that people who try to reduce rape to either sex or violence miss its complexity" (de Waal 2000). He went on to make a number of specific criticisms for instance that about one-third of rapes are of women too young or too old to bear children.

Now, humans share much of our biology with our close evolutionary relatives but two points need to be made. First, when we observe the behaviours of our closest evolutionary relatives - the various species of great ape - we find considerable variability between them with regards to such things as preferred group size, sexual behaviour and feeding behaviour. It is clear that behaviours can change substantially over relatively shorts periods of evolutionary time. Secondly, and more fundamentally, although it is always risky to attempt to identify the ways in which humans are unique (there are large literatures on the extent to which tool use, language and intelligence are defining human characteristics), it is clear that one of the notable features of our species is the extent to which we can choose how to behave.

The importance of human rationality in our ethical thinking was made with particular clarity by the moral philosopher Peter Singer in his book The Expanding Circle (Singer 1981). What Singer did was to argue that altruism began as a drive to protect one's kin and those in one's community but has developed over time into a consciously chosen ethic with an expanding circle of moral concern. In other words, what begins as pure evolutionary biology develops into something more than that. I think this is absolutely correct and much the same thing happens with many other areas of human thought and endeavour. There are probably biological explanations for the origins of music, dance, language, religion and mathematics, but one needs more than biology to understand the Brandenburg Concertos, The Rite of Spring, Ulysses, the doctrine of the Trinity and the proof of Fermat's Last Theorem.

A common worry about evolutionary ethics is that other species have very different rules from us as to what is appropriate behaviour. As is so often the case, Darwin got early on to the essence of the issue:

I do not wish to maintain that any strictly social animal, if its intellectual faculties were to become as active and as highly developed as in man, would acquire exactly the same moral sense as ours. In the same manner as various animals have some sense of beauty, though they admire widely-different objects, so they might have a sense of right and wrong, though led by it to follow widely different lines of conduct. If, for instance, to take an extreme case, men were reared under precisely the same 
conditions as hive-bees, there can hardly be a doubt that our unmarried females would, like the worker-bees, think it a sacred duty to kill their brothers, and mothers would strive to kill their fertile daughters; and no one would think of interfering.

(Darwin 1871, 67)

To this we can respond that if honey bees evolved the same cognitive capacities that we have, they might actually come to question whether some of their ancestral practices should persist. After all, humans have (on an optimistic reading) made considerable progress with regards to prohibiting slavery and, in many countries, to reducing sexism and treating children as having certain rights; so too, we could envisage campaigns among honey bees against the slaughter of conspecifics (cf. FitzPatrick 2017).

\section{RELIGION}

So, what is the place of religion in ethics? I have argued that our capacity for ethical reasoning had its roots in our biological nature but was then hijacked, though a sort of bootstrapping - 'cranes' in Daniel Dennett's (1995) terminology - as the human mind became increasingly powerful and sought for internal consistency in its reasoning. The result is that humans (some of them, at least) increasingly became convinced by the validity of what John Rawls (1971) would later express as decision-making behind a 'veil of ignorance' - namely that we should make ethical decisions as if we did not know our own position (back to Kant's categorical imperative). So, for example, laws about gender should be made by individuals genuinely setting aside whether they themselves are male, female or other; laws about immigration should be made without the presumption that one is or is not a migrant, and so on.

At first sight, it might be thought that this growth in human understanding about ethics doesn't fit very well with insights from religion aside from generic religious injunctions to do as one would be done by. After all, most religions are rather ancient in origin and contain something of a mish-mash of ethical injunctions and stories of the good in action. However, both for the believer and for the unbeliever, there are a number of reasons why I think religions have a major role to play in how we should behave.

The first is because religions manifest themselves in communities. I mentioned above that none of derives our moral beliefs ex nihilo. If one is, for example, a Buddhist (of whatever persuasion), one is likely, along with other Buddhists, to have, or at least believe one should have, a particular commitment to non-violence, eschewing craving and demonstrating compassion. The internalisation and manifestation of this way of being is helped by the presence of others who share one's beliefs. It is not a coincidence that the term ethics derives from ethos, i.e. custom or habit; we mostly exercise our behaviours in the presence of others with comparable values, and religions promulgate ethical values that are good for communities not just for individuals.

A second reason is because the world's major religions have developed over long periods of time and have therefore gone through processes of refinement (for all that they often begin with one or more acts of revelation) that share some similarities with the testing and sifting 
of natural selection. In other words, we have reasons to place considerable trust in longstanding institutions that genuinely seek to do good. This, of course, is one reason why more recent humanist / secular organisations often come up with principles that, as far as ethics are concerned, have considerable similarities with those of religion. When I read, for instance, books on humanism by Richard Norman (Norman 2004) or Andrew Copson (Copson 2018), there is much about ethics with which I find myself in agreement.

Religions, though, do have one major difference from humanist and secular approaches to ethics and that is that religious adherents generally attach more weight to religious teachings than agnostics and atheists do to secular teachings. This, of course, can be a problem. It can mean that religious believers become convinced of a particular reading of their scriptures or the sayings / teachings of their leaders. To make an obvious point - much injustice on women has been meted out in the name of religions because of this. More generally, as Mary Warnock puts it:

The danger of religion, any religion, lies in its claim to absolute immutable moral knowledge which, if justified, would indeed give its adherents a special place in instructing others how to behave, perhaps even a right to do so.

(Warnock 2010, 165)

However, religions develop in their teachings and also have the capacity to lift us up, to help us do good and to become new people in ways that on our own we could not manage; they can help us to turn over a new leaf, to start afresh, to be born again. This is the case whether one believes in a transcendental God or not. As Esther Reed puts in when writing about Christian ethics:

Christian living flows from belief in Christ, participation in the life of the church, the sacraments, prayer and fellowship. It concerns learning to live according to the 'mind of Christ' (Phil. 2:5) and as 'the body of Christ' (1 Cor. 12:27; Eph. 4:12; Col. 1:18), and involves the articulation and application of Christian belief and doctrine in specific situations.

(Reed 2000, ix-x)

For Christians, there are a range of ways of understanding how to use scripture, the teachings of the Church and reason to determine what is ethical (Fletcher 1966; Jones 1984; Cupitt 1988; Parson 1996; Gill 1999; Ward 2013). Whichever approach is used, the accounts of the life and teaching of Jesus are at least important; for many, they are determinative. Whether one goes by Thomas à Kempis' The Imitation of Christ or more contemporary, though often derided, bumper stickers or bracelets proclaiming 'WWJD' (What Would Jesus Do?), the notion that the goal of the Christian life is to be conformed to the image of God's Son has scriptural warrant (Romans 8:29).

This can be seen as a form of virtue ethics; that, however, much one fails, the Christian is called to model their life on that of Jesus of Nazareth, the risen Christ. Like any virtue ethics, there is the worry that right behaviour and action only makes sense within the confines of a particular time and place (Maclntyre 1981). But basing one's ethics on the one whom Christians see as both the author of the universe and the subject of the New Testament has 
advantages not just, of course, for Christians but for others too. When we consider the problems that arise from human selfishness and other moral failings, there is much in the person and teachings of Jesus and subsequent Christian theology, beginning in the New Testament itself, that can lead to healing and wholeness, for individuals, for communities and for the whole of creation.

\section{REFERENCES}

Abrahams, Ian and Reiss, Michael. 2012. "Evolution." In The Routledge International Handbook of Learning, Jarvis, P. with Watts, M. (Eds), 411-18. Abingdon: Routledge.

Barlow, Horace Basil. 1953. "Summation and inhibition in the frog's retina." Journal of Physiology 119:69-88.

Copson, Andrew. 2017. Secularism: Politics, religion, and freedom. Oxford: Oxford University Press.

Cupitt, Don. 1988. The New Christian Ethics. London: SCM Press.

Darwin, Charles. 1859. On the Origin of Species by Means of Natural Selection, or the Preservation of Favoured Races in the Struggle for Life. London: John Murray.

Darwin, Charles. 1871. The Descent of Man, and Selection in Relation to Sex. London: John Murray.

Darwin, Charles. 1872. The Expression of the Emotions in Man and Animals. London: John Murray.

Dawkins, Richard. 1976. The Selfish Gene. Oxford: Oxford University Press.

de Waal, Franciscus Bernardus Maria. 2000. "Survival of the rapist." The New York Times, April 2. Available at http://movies2.nytimes.com/books/00/04/02/reviews/000402.002walt.html.

de Waal, Franciscus Bernardus Maria, Churchland, Patricia Smith, Pievani, Telmo and Parmigiani, Stefano. 2014. Evolved Morality: The biology and philosophy of human conscience. Leiden: Brill.

Dennett, Daniel. 1995. Darwin's Dangerous Idea: Evolution and the meanings of life. New York: Simon \& Schuster.

FitzPatrick, William, J. 2017. "Why Darwinism does not debunk objective morality." In: The Cambridge Handbook of Evolutionary Ethics, Ruse, Michael and Richards, Robert J. (Eds), 188-201. Cambridge: Cambridge University Press.

Fletcher, Joseph. 1966. Situation Ethics: The new morality. Philadelphia: Westminster Press. Foot, Phillipa. 1967. "The problem of abortion and the doctrine of the double effect." Oxford Review 5:5-15.

Gill, Robin. 1999. Churchgoing and Christian Ethics. Cambridge: Cambridge University Press. Habermas, Jürgen. 1983. Moralbewusstsein und Kommunikatives Handeln. Frankfurt am Main: Suhrkamp Verlag.

Hauser, Marc D. 2006. Moral Minds: How nature designed our universal sense of right and wrong. Melbourne: Echo.

Jones, Richard G. 1984. Groundwork of Christian Ethics. London: Epworth Press.

Kant, Immanuel. 1785/2012. Groundwork of the Metaphysics of Morals. Cambridge: Cambridge University Press.

Kristjánsson Kristján. 2015. Aristotelian Character Education. London: Routledge.

MacIntyre, Alasdair. 1981. After Virtue. London: Duckworth. 
Maienschein, Jane and Ruse, Michael. 1999. Biology and the Foundation of Ethics. Cambridge: Cambridge University Press.

Martin, Patricia A. 1999. "Bioethics and the whole: pluralism, consensus, and the transmutation of bioethical methods into gold." Journal of Law, Medicine \& Ethics 27:316-27.

Moreno, Jonathan D. 1995. Deciding Together: Bioethics and moral consensus. Oxford: Oxford University Press.

Norman, Richard. 2004. On Humanism. Abingdon: Routledge.

Nowak, Martin A. and Coakley, Sarah. (Eds) 2013. Evolution, Games, and God: The principle of cooperation. Cambridge, MA: Harvard University Press.

O'Neill, Onora. 1996. Towards Justice and Virtue: A constructive account of practical reasoning. Cambridge: Cambridge University Press.

Parfit, Derek. 2011. On What Matters: Volume 1. Oxford: Oxford University Press.

Parsons, Susan Frank. 1996. Feminism and Christian Ethics. Cambridge: Cambridge University Press.

Rawls, John. 1971. A Theory of Justice. Cambridge, MA: Harvard University Press.

Reed, Esther D. 2000. The Genesis of Ethics: On the authority of God as the origin of Christian ethics. London: Darton, Longman and Todd.

Reiss, Michael. 1999. "Bioethics." Journal of Commercial Biotechnology 5:287-93.

Reiss, Michael Jonathan. 2002. "Introduction to ethics and bioethics." In Bioethics for Scientists, Bryant, John, Baggott-Lavelle, Linda and Searle, John (Eds), 3-17. New York: Wiley Liss.

Ruse, Michael and Richards, Robert J. (Eds) 2017. The Cambridge Handbook of Evolutionary Ethics. Cambridge: Cambridge University Press.

Singer, Peter. 1981. The Expanding Circle: Ethics, evolution, and moral progress. Princeton: Princeton University Press.

Singer, Peter. 2011. Practical ethics ( $3^{\text {rd }}$ edn). Cambridge: Cambridge University Press.

Sober, Elliott and Wilson, David Sloan. 1998. Unto Others: The evolution and psychology of unselfish behavior. Cambridge, MA: Harvard University Press.

Thornhill, Randy \& Palmer, Craig T. 2000. A Natural History of Rape: Biological bases of sexual coercion. Cambridge, MA: MIT Press.

Unger, Peter. 1996. Living High and Letting Die. Oxford: Oxford University Press.

Ward, Keith. 2013. Morality, Autonomy, and God. London: Oneworld.

Warnock, Mary. 2010. Dishonest to God. London: Continuum.

Wilkinson, Gerald S. 1984. "Reciprocal food sharing in the vampire bat." Nature 308:181-4.

Woodford, Peter J. 2018. The Moral Meaning of Nature: Nietzsche's Darwinian religion and its critics. Chicago: University of Chicago Press. 